\title{
RECTAL TRICHOMONAS VAGINALIS INFECTION IN SOUTH AFRICAN MEN WHO HAVE SEX WITH MEN
}

\section{$\underline{\text { Authors }}$}

Charlotte M. Hoffman ${ }^{1,2}$, Lise Fritz ${ }^{1}$, Oscar Radebe ${ }^{1}$, Dubbink $\mathrm{JH}^{1}$, James A. McIntyre ${ }^{1,3}$, Marleen M. Kock ${ }^{4,5}$, Remco P.H. Peters ${ }^{1,2,5^{*}}$

\section{$\underline{\text { Affiliations }}$}

1. Anova Health Institute, Johannesburg, South Africa

2. Department of Medical Microbiology, School of Public Health \& Primary Care (CAPHRI), Maastricht University, Maastricht, The Netherlands

3. School of Public Health \& Family Medicine, University of Cape Town Cape Town South Africa

4. Tshwane Academic Division, National Health Laboratory Service, Pretoria, South Africa

5. Department of Medical Microbiology, University of Pretoria, Pretoria, South Africa

\section{Footnotes}

${ }^{1}$ These first authors contributed equally to this article.

\section{*Correspondence}

Address for correspondence: Prof R.P.H. Peters, Anova Health Institute, 12 Sherborne Road, Parktown, PostNet Suite 242, Private Bag X30500, Houghton, South Africa. Email:

peters@ anovahealth.co.za. Tel: +27 115815000. 


\begin{abstract}
This study from South Africa highlights the importance of rectal Trichomonas vaginalis infection as a sexually transmitted infection among men who have sex with men (MSM). We report seven MSM presenting with rectal T. vaginalis infection. Two men presented with symptoms of proctitis; 5/7 had urethral coinfection with T. vaginalis. Rectal T. vaginalis infection should be considered in MSM in areas where genital infection is endemic.
\end{abstract}

Keywords Africa, homosexual, location, other, protozoal disease, trichomoniasis (Trichomonas vaginalis)

Sexually transmitted infections (STIs), in particular Chlamydia trachomatis and Neisseria gonorrhoeae, are common in men who have sex with men (MSM) in Africa. A study from Cape Town reported an overall prevalence of $24 \%$ among 200 MSM; the majority of men were asymptomatic. ${ }^{1}$ Rectal infection was common in this study (20\%) with similar prevalence for C. trachomatis and N. gonorrhoeae infection (12\%). Another study reported an overall prevalence of $11.6 \%$ for these rectal infections among Kenyan MSM. ${ }^{2}$

Trichomonas vaginalis is the most common non-viral STI in Africa. ${ }^{3}$ Women are more often affected, with prevalence reported up to $24 \%$ in South Africa, but urethral infection in men is not uncommon. ${ }^{4,5}$ For example, a study from Johannesburg, South Africa, showed that $T$. vaginalis is the etiological cause in $6.1 \%$ of cases of male urethritis syndrome. ${ }^{6}$ Despite the significance of $T$. vaginalis as cause of urethral infection in men with urethral discharge, the occurrence of rectal T. vaginalis infection in African MSM remains undocumented.

To our knowledge, only a few studies have reported before on rectal $T$. vaginalis infection in MSM: 2/225 men (0.9\%) tested positive in the study by Cosentino et al. whereas 3/500 (0.6\%) had a positive PCR test for T. vaginalis in another study. ${ }^{7,8}$ Both studies were conducted in the 
United States where the prevalence of $T$. vaginalis infection in the general population is much lower than in Africa. ${ }^{9}$ In a study conducted in Côte d'Ivoire, where T. vaginalis infection is more common in the population, $2 / 94(2.1 \%)$ male sex workers tested positive for rectal $T$. vaginalis. $^{10}$

To determine the prevalence of urethral and rectal STIs among South African MSM, we analyzed specimens collected in a prospective study of STIs among MSM attending a public healthcare facility in Johannesburg, South Africa. ${ }^{11,12}$ Briefly, MSM ( $\geq 18$ years) with urethral discharge and/or signs of proctitis (i.e. rectal discharge and/or blood loss) were recruited in this study. After obtaining informed consent, they were tested for urethral and rectal C. trachomatis, $N$. gonorrhoeae, T. vaginalis and M. genitalium infection by collecting respectively urine samples and clinician-collected rectal swabs; treatment was provided as per local guidelines. A follow-up visit was conducted after 6 weeks and repeat STI testing was performed. Besides diagnostic testing for other STIs, detection of T. vaginalis was done following DNA extracting using the High Pure PCR Template Preparation Kit [Roche Diagnostics, Basel, Switzerland] with a specifically targeted real-time PCR assay. ${ }^{13}$ Positive reactions were confirmed with the Presto $^{\text {Plus }}$ CT/NG/TV assay [Microbiome Ltd., Houten, The Netherlands]. ${ }^{14}$ At recruitment a total of 7/78 individual MSM (9.0\%; 95\% CI 5.7-12\%) tested positive for rectal T. vaginalis infection. Rectal swabs of 3/78 (3.8\%; 95\% CI 3.4-4.3\%) men tested positive for T. vaginalis infection upon recruitment; two of these men had concurrent urethral $T$. vaginalis infection. At follow-up, 4/61 (6.6\%; 95\% CI 5.8-7.4\%) different MSM were positive for rectal T. vaginalis infection; three had concurrent urethral infection. All men were treated with metronidazole (oral, $400 \mathrm{mg}$ TDS for seven days) and none of them had clinically persistent infection (i.e. urethral discharge, dysuria or symptoms of proctitis).

The demographic, behavioral and clinical characteristics of the seven individual MSM with rectal T. vaginalis infection are summarized in Table 1 . The age range was $24-40$ years and 
Table 1. Summary of the case series, Johannesburg, South Africa, 2016.

\begin{tabular}{|c|c|c|c|c|c|c|c|}
\hline Variable & Case 1 & Case 2 & Case 3 & Case 4 & Case 5 & Case 6 & Case 7 \\
\hline $\begin{array}{l}\text { Demographics } \\
\text { Age } \\
\text { Race } \\
\text { Employment status } \\
\text { HIV status } \\
\text { ART } \\
\text { Sexual orientation } \\
\text { Sexual preference }\end{array}$ & $\begin{array}{l}24 \\
\text { Black } \\
\text { Employed } \\
\text { Positive } \\
\text { Pre-ART } \\
\text { Gay } \\
\text { Men }\end{array}$ & $\begin{array}{l}36 \\
\text { Black } \\
\text { Unemployed } \\
\text { Negative } \\
\text { NA } \\
\text { Gay } \\
\text { Men }\end{array}$ & $\begin{array}{l}40 \\
\text { White } \\
\text { Unemployed } \\
\text { Declined } \\
\text { NA } \\
\text { Gay } \\
\text { Men }\end{array}$ & $\begin{array}{l}27 \\
\text { Black } \\
\text { Employed } \\
\text { Positive } \\
\text { Yes } \\
\text { Gay } \\
\text { Men }\end{array}$ & $\begin{array}{l}40 \\
\text { Black } \\
\text { Employed } \\
\text { Positive } \\
\text { Yes } \\
\text { Gay } \\
\text { Men }\end{array}$ & $\begin{array}{l}31 \\
\text { Black } \\
\text { Employed } \\
\text { Negative } \\
\text { NA } \\
\text { Gay } \\
\text { Men }\end{array}$ & $\begin{array}{l}32 \\
\text { Black } \\
\text { Employed } \\
\text { Positive } \\
\text { No } \\
\text { Gay } \\
\text { Men }\end{array}$ \\
\hline \multicolumn{8}{|l|}{ Behavioural factors } \\
\hline $\begin{array}{l}\text { Sexual partners } \\
\text { No. of male sex partners } \\
\text { past } 6 \text { months }\end{array}$ & 1 & 1 & 4 & 4 & 1 & 7 & 2 \\
\hline $\begin{array}{l}\text { No. of female sex } \\
\text { partners past } 6 \text { months }\end{array}$ & 0 & 0 & 0 & 0 & 0 & 7 & 0 \\
\hline $\begin{array}{l}\text { Sexual orientation of } \\
\text { partner }\end{array}$ & Gay & Gay & Gay & Gay & Gay & Bisexual & Gay \\
\hline Stable relationship & No & $\begin{array}{l}\text { Yes }(1 \\
\text { person) }\end{array}$ & No & $\begin{array}{l}\text { Yes }(>1 \\
\text { person })\end{array}$ & $\begin{array}{l}\text { Yes }(1 \\
\text { person) }\end{array}$ & No & No \\
\hline \multicolumn{8}{|l|}{ Sex act } \\
\hline Anal intercourse & Receptive & Versatile & Versatile & Versatile & Insertive & Insertive & Versatile \\
\hline Anal use of sex toys & & & $\begin{array}{l}\text { Dildo, } \\
\text { vibrator, } \\
\text { anal beads }\end{array}$ & & No & Dildo & \\
\hline $\begin{array}{l}\text { Condom use during RAI } \\
\text { Extra }\end{array}$ & Always & Never & Never & Sometimes & NA & NA & Sometimes \\
\hline $\begin{array}{l}\text { Pays goods or money } \\
\text { for sex }\end{array}$ & No & No & Yes & No & No & No & No \\
\hline \multicolumn{8}{|l|}{ Clinical presentation } \\
\hline Rectal symptoms & - & - & $\begin{array}{l}\text { Anal } \\
\text { discharge, } \\
\text { anal itch, } \\
\text { rectal } \\
\text { bleeding }\end{array}$ & - & - & - & $\begin{array}{l}\text { Anal } \\
\text { discharge }\end{array}$ \\
\hline $\begin{array}{l}\text { Penile discharge and/or } \\
\text { dysuria }\end{array}$ & + & + & + & + & + & + & - \\
\hline \multicolumn{8}{|l|}{ Infections } \\
\hline $\begin{array}{l}\text { Rectal } \\
\text { Urethral }\end{array}$ & $\begin{array}{l}\text { TV } \\
\text { NG }\end{array}$ & $\begin{array}{l}\text { TV, NG } \\
\text { TV, NG, MG }\end{array}$ & $\begin{array}{l}\text { TV } \\
\text { TV }\end{array}$ & $\begin{array}{l}\text { TV } \\
\text { TV, NG }\end{array}$ & $\begin{array}{l}\text { TV } \\
-\end{array}$ & $\begin{array}{l}\text { TV } \\
\text { TV, NG }\end{array}$ & $\begin{array}{l}\text { TV } \\
\text { TV, NG, }\end{array}$ \\
\hline
\end{tabular}

Table footnotes: NA, not applicable; RAI, receptive anal intercourse; NG, Neisseria gonorrhoeae; TV,

Trichomonas vaginalis; MG, Mycoplasma genitalium.

four men were HIV-infected. All men were gay-identified and reported male sex partners; only one reported recent concurrent female sex partners. Anal penetration was reported by six men: five men reported receptive anal intercourse (RAI) and two reported the anal use of sex toys. In one case (MSM number five) there was no direct anal sexual contact reported. Most patients reported inconsistent condom use. Anal discharge was present in two patients with one having severe symptoms of proctitis. 
This is the largest case series of rectal T. vaginalis infection in MSM reported to date. It shows that symptomatic and asymptomatic rectal $T$. vaginalis infection is common among MSM living in our area of high prevalence of genital infection. Although co-infections were detected in one MSM, our data suggest that $T$. vaginalis infection should be considered as etiological agent in case of proctitis in MSM. However, anal discharge in MSM is not included as condition in the syndromic management guidelines in our setting. ${ }^{15}$ Also, metronidazole in only added to the empirical treatment regimen in case the man reports a female sex partner with vaginal discharge; this was not the case in our study. T. vaginalis should be included in the debate when considering public health aspects of asymptomatic rectal STIs in MSM in Africa, since rectal STIs may increase susceptibility to and infectivity of HIV infection ${ }^{16}$ and asymptomatic rectal STIs are likely to remain untreated as diagnostic tests are not routinely available in our resource-constraint setting.

Our observations suggest that $T$. vaginalis may circulate within the MSM network and is not the result of direct bridging of infection from concurrent sexual contact with women. All men were gay and reported gay sex partners; only one also report recent sexual contact with women. In five men a potential urethral T. vaginalis infection of the partner could have been transmitted to the rectum during RAI. The anal use of sex toys would be a possible way of transmission in two men, since transmission of $T$. vaginalis without anal penetration and by use of fingers is described. ${ }^{17}$ The route of acquisition of the rectal infection in one patient remains unclear as he did not report any direct anal sexual contact.

A limitation of this study is that we cannot rule-out the possibility of misclassification of other non-vaginalis Trichomonad species which are (harmless) inhabitants of the rectum. However, 5/7 men had concurrent urethral $T$. vaginalis infection where these pathogens do not occur, suggesting true rectal $T$. vaginalis infection. 
In conclusion, we show that rectal $T$. vaginalis is an important infection in MSM living in an area where genital infection is endemic. More research is required to prove that the infection should be considered in the differential diagnosis of proctitis in MSM in our area and, in the absence of diagnostic tests, probably be covered in the empirical treatment choice. T. vaginalis should be considered when addressing the public health impact of rectal STIs among MSM in South Africa.

\section{Ethical approval}

This study was approved by the Human Research Ethics Committee of the University of the Witwatersrand, Johannesburg, South Africa (Ref: M150352).

\section{Acknowledgement}

We thank the patients for participating in this study as well as the staff at the Health4Men clinics in Johannesburg and at the laboratory of medical microbiology at the University of Pretoria for their support.

\section{Declaration of Conflicting Interests}

The Authors declare that there is no conflict of interest. 


\section{REFERENCES}

1. Rebe K, Lewis D, Myer L, et al. A Cross Sectional Analysis of Gonococcal and Chlamydial Infections among Men-Who-Have-Sex-with-Men in Cape Town, South Africa. PLoS One 2015; 10:e0138315.

2. Sanders EJ, Thiong'o AN, Okuku HS, et al. High prevalence of Chlamydia trachomatis and Neisseria gonorrhoeae infections among HIV-1 negative men who have sex with men in coastal Kenya. Sex Transm Infect 2010; 86:440-441.

3. World Health Organization. (2008). Global prevalence and incidence of selected curable sexually transmitted infections: overviews and estimates. World Health Organization 2008. (Available: http://apps.who.int/iris/bitstream/10665/75181/1/9789241503839_eng.pdf?ua=1). [Accessed: 14 Jan 2017].

4. Mudau M, Peters RP, de Vos L, et al. High prevalence of asymptomatic sexually transmitted infections among human immunodeficiency virus-infected pregnant women in a low-income South African community. Int J STD AIDS 2018; 29(4):324-333.

5. De Waaij DJ, Dubbink JH, Peters RP, et al. Prevalence of Trichomonas vaginalis infection and protozoan load in South African women: a cross-sectional study. BMJ Open 2017; 7:e016959.

6. Lewis DA, Marsch K, Radebe F, et al. Trends and associations of Trichomonas vaginalis infection in men and women with genital discharge syndromes in Johannesburg, South Africa. Sex Transm Infect 2013; 89:523-527.

7. Cosentino LA, Campbell T, Jett A, et al. Use of Nucleic Acid Amplification Testing for Diagnosis of Anorectal Sexually Transmitted Infections. J Clin Microbiol 2012; 50:2005-8.

8. Francis SC, Kent CK, Klausner JD, et al. Prevalence of rectal Trichomonas vaginalis and Mycoplasma genitalium in male patients at the San Francisco STD clinic, 2005-2006. Sex Transm Dis 2008; 35:797-800. 
9. Miller WC, Swygard H, Hobbs MM, et al. The prevalence of trichomoniasis in young adults in the United States. Sex Transm Dis 2005; 32:593-8.

10. Vuylsteke B, Semde G, Sika L, et al. High prevalence of HIV and sexually transmitted infections among male sex workers in Abidjan, Côte d'Ivoire: need for services tailored to their needs. Sex Transm Dis 2012; 88:288-293.

11. Peters RP, Radebe O, Hamiwe T, et al. P3.190 High rate of repeat sexually transmitted infections among men who have sex with men in South Africa. Sex Transm Infect 2017; 93(S2):A164.

12. Rees K, Radebe O, Arendse C, et al. Utilization of sexually transmitted infection services at 2 health facilities targeting men who have sex with men in South Africa: a retrospective analysis of operational data. Sex Transm Dis 2017; 44(12):768-773.

13. Pillay A, Radebe F, Fehler G, Htun Y, Ballard RC. Comparison of a TaqMan-based realtime polymerase chain reaction with conventional tests for the detection of Trichomonas vaginalis. Sex Transm Infect 2007; 83:126-9.

14. De Waaij DJ, Ouburg S, Dubbink JH, Peters RP, Morré SA. Evaluation of Presto(plus) assay and LightMix kit Trichomonas vaginalis assay for detection of Trichomonas vaginalis in dry vaginal swabs. J. Microbiol Method 2017; 127:102-104.

15. Department of Health; Republic of South Africa. Sexually transmitted infections management guidelines, 2015. (Available from: http://www.kznhealth.gov.za/family/STIguidelines-2015.pdf) [15 March 2017].

16. Kiviat NB, Critchlow CW, Hawes SE, et al. Determinants of Human Immunodeficiency Virus DNA and RNA Shedding in the Anal-Rectal Canal of Homosexual Men. J Infect Dis $1998 ; 177: 571-78$

17. Kellock D, O’Mahony CP. Sexually acquired metronidazole-resistant trichomoniasis in a lesbian couple. Genitourin Med 1996; 72:60-61. 